\title{
Public Policy in Central America: An Empirical Analysis
}

\author{
Kern William Craig ${ }^{1}$ \\ ${ }^{1}$ Department of Political Science, Troy University, Troy, AL 36082, United States \\ Correspondence: Kern William Craig, Department of Political Science, Troy University, Troy, AL 36082, United \\ States. E-mail: kcraig38002@troy.edu
}

Received: July 13, 2013 Accepted: July 31, 2013 Online Published: September 29, 2013

doi:10.5539/par.v2n2p105

URL: http://dx.doi.org/10.5539/par.v2n2p105

\begin{abstract}
This is a cross-sectional study focusing on public policy in the seven nations of Central America: Belize, Costa Rica, El Salvador, Guatemala, Honduras, Nicaragua, and Panama. Outcomes are evaluated in terms of public wellbeing. Public policy is operationalized: with regard to business using two measures, one for economic freedom and another for corporate taxation; with regard to ethics using two measures, one for gender equality and another for corruption; with regard to openness using four measures, two external, trade and tourism, and two internal, the number of roads in a country and the number whites in a country; and with regard to contraception using a single measure, fertility. Public wellbeing is operationalized using: three economic measures, GDP per capita, lost income, and poverty rate; four societal measures, literacy rate, homicide rate, life expectancy, and lost satisfaction; and, two holistic measures, the Human Development Index and the Environmental Performance Index. Pearson correlation is used to calculate the linear association for each pair of measures. The results suggest that there is no relationship between public wellbeing and two measures of public policy: gender equality and the number of roads in a country. But there is evidently a relationship between public wellbeing and the remaining seven measures of public policy: economic freedom, corporate taxation, corruption, trade, tourism, the number of whites in a country, and fertility. And the direction of those seven relationships supports the claims of capitalists as opposed to the claims of socialists.
\end{abstract}

Keywords: Central America, public policy, capitalism, neoliberal, socialism, fascist, communist, dependency

\section{Introduction}

This is a cross-sectional study focusing on public policy in the seven nations of Central America: Belize, Costa Rica, El Salvador, Guatemala, Honduras, Nicaragua, and Panama. Outcomes are evaluated in terms of public wellbeing. A regional study is appropriate because "transnational trends ... operated in Central America ... before the establishment of separate states ... and their impact continued thereafter" (Roniger, 2011, p. 10).

The Spanish Kingdom of Guatemala encompassed all of Central America at one time or another. Political unification dates from the establishment of a regional court, the Audiencia de los Confines, in 1542. Its jurisdiction in the Kingdom of Guatemala "survived beyond the end of Spanish rule" but only just (Woodward, 2008, p. 16-22). After independence from Spain (1821), the Kingdom of Guatemala was superseded by the United Provinces of Central America (1823), aka the Federal Republic of Central America (1824), the Confederation of Central America (1842), the National Representation of Central America (1851), the Federation of Central America (1852), the Greater Republic of Central America (1896), and the United States of Central America (1898). Life was turbulent and short for these attempts at political union.

Regional associations in the $20^{\text {th }}$ century included the Central American Court of Justice (1907), the Central American Labor Council (1925), the Organization of Central American States (1951), the Multilateral Treaty on Free Trade and Central American Economic Integration (1958), the Central American Common Market (1960), the Central American Bank for Economic Integration (1960), the Central American Defense Council (1964), the Central American Monetary Council (1964), the Central American Parliament (1991), the Central American Integration System (1991), the Central American Court of Justice (reconfigured 1992), the Central American Free Trade Zone (1993), the Alliance for the Sustainable Development of Central America (1994), the Central American Social Integration System (1995), and the Framework Treaty on Democratic Security in Central America (1995). Now, in the $21^{\text {st }}$ century, there is the Central America Free Trade Agreement (2004) aka the United States-Dominican Republic-Central America Free Trade Agreement. 
The initial level of analysis for this study is national rather than regional because sovereign states are "crucial actors in both the internal and international scene" (Roniger, 2011, p. xiii). And most data are measured and collected at the national as opposed to the regional level. Although national measures can conceal variation within countries, they can nevertheless reveal variation between countries. And although national measures are not reflections of specific individuals, they are nonetheless reflections of individual countries.

Since, however, the final level of analysis is regional, countries are not ranked or otherwise compared in terms of one another. Instead, indicators for the variables of interest are compared and correlated in terms of one another. And, because this study is contemporary as opposed to historical, the direction of correlation is the focus as opposed to the direction of causation. Using only current data, sequential tests are not possible. But government is supposed to govern and govern well. So it is logically possible to assume that public policy is the explanatory variable or "cause" whereas public wellbeing is the dependent variable or "effect."

The explanatory variable is categorized in terms of government policy involving business, ethics, openness, and contraception. The dependent variable is categorized in terms of economic, societal, and holistic outcomes. Nine measures of public policy and nine measures of public wellbeing form the symmetric structure of the econometric model.

This study is objective as opposed to subjective. It is not only empirical it is also positivist. Factual evidence is used to test theoretical propositions with induction juxtaposed to deduction. But this research is merely exploratory. And Pearson correlation is the only methodology employed to evaluate relationships between measures.

Each bivariate hypothesis corresponds to propositions drawn from the politicized literature of the region. Each epitomizes the standoff between capitalists and socialists (Molina and Palmer 1998, 58), between those who stress the production of wealth and those who stress the distribution of wealth (Biesanz, Biesanz, \& Biesanz, 1999, p. 101). Each is illustrative of the argument between champions of the private sector and champions of the public sector, between those who favor supply and demand and those who favor command and control.

Each bivariate hypothesis is symbolic of the debate between those who prefer constitutional democracy and the rule of law and those who prefer totalitarian dictatorship and the rule of a personalistic, clientelistic, and/or militaristic (Woodward 2008, 104-5) "caudillo or strongman" (Marti i Puig, 2010, p. 89, 98) or a "vanguard" of the proletariat such as the Popular Vanguard Party (Lehoucq, 2010) or the Frente Sandinista de Liberacion Nacional (Marti i Puig, 2010, p. 83) (Kinzer, 1991, p. 173).

In other words, each bivariate hypothesis is representative of an enduring dispute: between moderates and extremists whether from the reactionary right or the revolutionary left; between individualists and collectivists whether they are corporatists or unionists (Torres-Rivas, 1993, p. 106, 15); between egalitarians and sexists whether patriarchal or matriarchal; and, between minimalists and statists whether promoters of big brother and a police state or big nanny and a welfare state.

Each empirical test is therefore two-tailed with outcomes in one tail validating capitalist or neo-liberal policy and with outcomes in the other tail validating socialist policy whether neo-fascist or neo-communist like the "indigenous villages (of Central America) ... caught between two fires," the army and the guerrillas, until there was "a shift in the 1990s toward democratization and market openings" (Roniger, 2011, p. 112, 3).

Some might contend that "there is no apolitical science" (Weinberg, 1991, p. 146). But here it is objectively assumed that each measure of public policy is associated with each measure of public wellbeing in a positive or negative way or not at all. In other words, all three possibilities are treated as equally plausible. And here it objectively hypothesized that no relationship exists between the measures of interest. Therefore the presence of association leads one to reject the null hypothesis whereas the absence of association leads one to fail to reject it.

\section{Literature Review}

\subsection{Hypothesis 1}

There is no relationship between economic freedom and the nine measures of public wellbeing.

Profound differences separate the proponents of government controls from the proponents of free markets. Under the Sandinistas in Nicaragua, "the people became the collective owners of 20 percent of the arable land, numerous industrial and commercial enterprises, and thousands of private homes and mansions ... (as well as) the banking and insurance systems" and later "other properties were nationalized for reasons of overriding national interest" (Walker \& Wade, 2011, p. 99). In Costa Rica, the situation was much different. "Neoliberal governments sold off ... (some) inefficient firms ... (in the) state-directed industrial sector ... (and) eliminated (some) price supports" to promote greater economic freedom (Lehoucq, 2010). 
"Concessional finance from ... multilateral institutions (the International Monetary Fund, World Bank and International Development Agency) ... meant acceptance of a degree of 'structural adjustment' ... cuts in government spending ... and a program of privatization" throughout the Central American region (Thomson, 2004, p. 181). The focus was not only on economic progress but also environmental protection. "Neoliberal environmental government" was characterized by "marketization ... the deployment of market rationality to an ever-broader range of contexts ... (and) destatization ... the devolution of responsibilities traditionally undertaken by states to nonstate entities ranging from NGOs to for-profit businesses to communities and individuals" (Medina, 2010, p. 247).

As a rule, socialists are proponents of governmental control and public property whereas capitalists are proponents of personal freedom and private property. And "the policy shift by the international financial institutions (IFIs) in support of indigenous land rights ... a recognition of the collective over the individual ... has been framed as a type of 'indigenous exceptionalism' ... a limited and isolated 'exception' that does not fundamentally challenge the ... universality of markets, consumption, individualism and individual property rights that undergird the IFIs' broader neoliberal model" (Horton, 2006, p. 841).

\subsection{Hypothesis 2}

There is no relationship between corporate taxation and the nine measures of public wellbeing.

The socialist model of big government entails high rates of taxation. Conversely, the capitalist model of small government entails low rates of taxation. And a turn to the socialist left usually involves an even more "substantial rise in taxes" than a turn to the socialist right (Anderson, 188, p. 143). After the revolution in Nicaragua, "many rural and urban properties were seized, and stiff taxes were levied on property, income," etc. (Walker \& Wade, 2011, p. 128).

In Belize, the government attempted to walk the straight and narrow avoiding extreme policies both left and right. It stepped up its "effort to attract inward investment ... (and) 100 percent foreign ownership of businesses is allowed, and a range of tax exemptions is offered new enterprises ... in the Commercial Free Zone" (Thomson, 2004, p. 183).

"The neoliberal model of economics ... is used to describe the ... emphasis on the free market, international trade, (and) a very limited role for government" (Walker \& Wade, 2011, p. 106). "Throughout Latin America, neoliberalism featured (1) the downsizing of government; (2) privatization of state-owned enterprises; (3) deregulation of private enterprise; (4) and a sharp reduction in or an elimination of tariff barriers to foreign trade" (ibid). But leftists continue to oppose all such measures, especially "tax incentives" for business, as "a race to the bottom" (Roniger, 2011, p. 181).

\subsection{Hypothesis 3}

There is no relationship between gender equality and the nine measures of public wellbeing.

"The concept of machismo is very important ... in ladino society ... handed down from the time of the conquistadores" (Anderson, 1988, 14). "A lot of Latin attitudes toward women are chauvinistic ... (and) recourse to violence is aggravated by the persistence of machismo" (Biesanz, Biesanz \& Biesanz, 1999, p. 186, 190). The same is also true with respect to most Indian tribes of Central America. Indigenous groups are "permeated with inequities of gender" such as "the exclusion of women from ... governance" (Horton, 2006, p. 846).

"The Sandinista Revolution by no means brought complete equality to women ... Domestic violence continued ... (and) abortion remained technically illegal" (Walker \& Wade, 2011, p. 126). "As elsewhere in Latin America, values ... connected with the concept of machismo (manliness) have traditionally affected sex-roles ... A woman's place was in her home, and a strict double standard of sexual behavior applied" (ibid, p. 125).

"Families were often authoritarian ... marked by ... the implicit code that women tend to children and serve men" and employment outside the home like "trade unionism was perceived ... as a macho domain" (Levenson, 2011, p. 307-8). Countries were often more authoritarian than families. "The concentration of power in few hands ... created an ample arena for charismatic ... dictators ... (and) strong paternalism" (Perez-Brignoli, 1989, p. 106, 173).

But, after the most recent series of wars, "class conflict ... as fueled by socially motivated passion ... whether from the left or right ... seemed to recede ... as part of an ideological society of equals ... (and) the transition to ... global capitalist logic" (Moodie, 2010, p. 83). And even critics of "foreign capital" and the "neoliberal ethic" acknowledge "the opening of spaces for women in the professions, in business, in politics and in the arts" (Molina \& Palmer, 1998, p. 115, 135, 137). 
In Costa Rica, "the political and economic impact of the neoliberal model was palpable ... nearly 40 percent of the seats in the legislature were held by women ... (and) female participation in the workforce had risen sharply ... making Costa Rica a poster child for neoliberalism” (Booth, Wade, \& Walker, 2010, p. 71-72).

\subsection{Hypothesis 4}

There is no relationship between corruption and the nine measures of public wellbeing.

Leftists blame capitalism in general and the US in particular for anything that goes wrong in Central America including "the emergence of gangs ... (in) the 1940s ... (as) an epiphenomenon of the first major regional push toward capitalist modernization" and the reemergence of gangs in the 1990s with "the large scale deportation of Central American refugees from the United States" (Rodgers, 2012, p. 66) who "imported US style gang culture into their countries of origin" (Wolf, 2012, p. 43). But Central Americans themselves are largely to blame for such corruption.

"So weak are their judicial systems that in Guatemala, for example, only one murder in 20 is punished" ("Drug War Hits Central America," 2011). There is a "risk of Honduras becoming a failed state ... (with) gang violence, catalyzed by drug trafficking, and weak law enforcement" giving it "the highest murder rate in the world" ("Out of Control," 2013). "El Salvador was second only to Honduras in the UN's global murder rankings ... (and Salvadorans) complain that extortion, a way of life for the maras, has continued untamed" ("Year of Living Less Dangerously," 2013).

"Corruption in Honduran politics has always been an art, but (Policarpo) Paz (Garcia) and his cronies made it into a systematic science (1978-1982) ... almost every conceivable project was milked for kickbacks and graft ... (and) particularly important was the role of certain prominent officers in the narcotics trade" (Anderson, 1988, p. 144). His government also "infuriated ... the private-enterprise lobby, by announcing a substantial rise in taxes" that amounted to a flagrant shakedown of the business community (ibid, p. 143).

In Panama, Omar Torrijos Herrera "assumed dictatorial powers ... made an alliance with Panama's Communist Party ... (and) promised ... 'democracy without elections' ... Nepotism was rampant during Torrijos's rule (1968-1981) ... (and) Torrijos's own brother, Mochi, was infamous for his drug trafficking” (Harding, 2006, p. 67, $69,71,73$ ). "Clientelism, the bestowing of jobs or other advantages to supporters, was rampant, as was graft" (ibid, p. 65).

In 1983, Manuel Noriega seized upon a "power vacuum and promoted himself to general" becoming the "de facto leader" of Panama but "Noriega was more of a street thug who thrived on dread, vice, corruption, and fleeting material and carnal passions" not to mention "drug trafficking" (Harding, 2006, p. 93-5). It took a US invasion force, Operation Just Cause, to remove him from office in 1989.

In Nicaragua, misrule on the right was exceeded only by misrule on the left. "In the Somoza era, the number of secret police agents ... never exceeded a few hundred, but under the Sandinisitas, they numbered more than three thousand" (Kinzer, 1991, p. 179). "Turbas, pro-Ortega gangs, were ... used as a tool to intimidate the opposition ... (and) in the municipal elections of 2008 ... all credible international observation was ... barred ... another example of the corrupting nature" of the Sandinistas (Walker \& Wade, 2011, p. 78-9). Since then "Nicaragua's democracy has been castrated (if not raped) by Mr. Ortega" ("Tormented Isthmus," 2011) who "began an unconstitutional third term" as President in 2012 ("Surprising Safe Haven," 2012).

Corruption permeates many sectors of Central America society. There "is a widespread distrust of private-sector unions; many workers see union officials as corrupt and self-seeking” (Biesanz, Biesanz \& Biesanz, 1999, p. 58). "Public-sector unions' demands for higher pay, shorter hours, and greater fringe benefits" are resented since "most government employees are slow, inefficient, and rude" (ibid, p. 70).

"Corruption and administrative inefficiency have added to public distrust ... (and) public insecurity has led to citizens' retreat from public spheres" (Ronger, 2011, p. 182). But "the Honduran coup of 2009 and subsequent violent mass protests on both sides demonstrated the risks of a multi-dissatisfied and polarized citizenry" (Booth, Wade \& Walker, 2010, 264).

Some countries are however doing better than others. "Martin Torrijos, inaugurated as President of Panama in 2004, "was not a carbon copy of his populist father ... (He) arrived in office espousing ... much more market-oriented economics and 'zero-tolerance' anti-corruption policy" (Harding, 2006, p. 134-5).

Oscar Arias Sanchez, the President of Costa Rica, supported neoliberal reforms including the passage of the Central America Free Trade Agreement in 2009 making his country "much less dependent on remittances than its 
neighbors" (Booth, Wade \& Walker, 2010, p. 77). And Costa Rica now has less corruption than any other Central American nation except Panama (Seligson \& Smith, 2010c).

\subsection{Hypothesis 5}

There is no relationship between trade and the nine measures of public wellbeing.

Communists oppose trade claiming that it fosters "economic dependency on foreign markets" (Weinberg, 1991, p. 6). Instead, they advocate "self-sufficiency" as in "Central America's ability to feed itself independently" (ibid, p. 20). They maintain that "underdeveloped countries are hooked into a technological package ... loans from foreign banks to fund the importation of inputs ... the price on the world market for their agro-exports ... more loans and ... debt crisis" (ibid, p. 85-86).

In "1974, the representatives of most of the banana exporting countries ... formed the Union de Paises Exportadores de Banana ... (and) it was agreed that each nation would substantially hike its export duties" (Anderson, 1988, p. 136). The Sandinista government subsequently based its anti-trade policy on "Third World socialism" and imposed "strict control over exports" (Perez-Brignoli, 1989, p. 171).

The goal "of the Nicaraguan revolution and agrarian reform was to make the nation self-sufficient" (Weinberg, 1991, p. 90). And "reducing reliance on imports and foreign technological inputs was seen by some Sandinista militants as potentially more effective in alleviating the economic crisis than was the development of mega-scale projects to generate foreign exchange" (ibid, p. 92).

The leftist government of Jose Napoleon Duarte in El Salvador not only "put price controls on essential items" but also "prohibited the import of new cars and other "luxury' items" thus provoking "massive demonstrations" (Anderson, 1988, p. 117). Throughout Central America, growth alternatives based on import substitution were blocked by reduced national markets and the scarcity of financiers and technicians" not to mention the popularity of imported consumer goods (Torres-Rivas, 1993, p. 63, 101).

The differences between socialists and capitalists are clear in terms of "neoliberal structural adjustment ... promoting ... free markets ... (and) free trade zones" (Booth, Wade, \& Walker, 2010, p. 170), "neoliberal economic policies ... reducing trade barriers" (ibid, p. 71), "neoliberal programs of liberalization of trade and finances" (Roniger 2011, p. 150), and "neoliberal rationality that would facilitate transnational free-trade currents" (Moodie, 2010, p. 15).

"The controversy surrounding (the Central America Free Trade Agreement) ... perhaps best exemplified the tension between those who wished to continue the neoliberal model and those who wished to preserve ... welfare state" policies (Booth, Wade \& Walker, 2010, p. 78). And, "the neo-liberal development model could certainly claim some success in increasing trade" (Woodward 1999, 306).

\subsection{Hypothesis 6}

There is no relationship between tourism and the nine measures of public wellbeing.

Communist and indigenous movements generally opposed "the cultural project of neoliberalism" and specifically advocated a "moratorium on international tourism" (Hale, 2011, p. 520). The black "brain trust" of the "long-dominant People's United Party" in Belize were "counter-culturalists" who "wanted to slay the dragon of capitalism ... frowned on tourism" and were "reluctant to turn Belize into a nation of waiters" (Twigg, 2006, p. 137, 161, 197).

Leftists in Costa Rica complained "that 'waiters are paid better than teachers' ... (and) that large resorts attract thieves, prostitutes, drug dealers and entertainment falsely presented as authentic national folklore" (Biesanz, Biesanz \& Biesanz, 1999, p. 54). And dependentistas grumbled that "native people are presented as Guatemala's biggest tourist attraction ... 'exotic savages' ... (who) never get a fair price for creative work" (Velasquez-Nimatuj, 2011, p. 527).

The left maintains that "the rise in ... tourism has not added up to a model of sustainable development" yet in some countries "tourism is (the) principal earner of foreign exchange" (Molina \& Palmer, 1998, p. 137,128). One example of sustainable development "very popular in Costa Rica is nature tourism, sometimes ... called 'eco-tourism' ... attracting North American and European travelers" (Weinberg, 1991, p. 116). It "is a market-based mechanism for protecting ecosystems ... intended to endow protected areas with cash value in order to win support for ... conservation" (Medina, 2010, p. 248).

"Neo-liberal solutions to the economic and social underdevelopment of the region ... included ... tourism ... (and) tourism itself became an instrument for attracting potential investors" (Woodward, 1999, p. 293). Tourism was an 
important component of the much maligned "structural adjustment packages" of International Monetary Fund and the US Agency for International Development (Booth, Wade, \& Walker 2010, p. 170).

The "expanding tourist trade ... triggered ... economic growth and diversification ... (and) tourists ... brought much needed foreign exchange" (Woodward, 2008, p. 161, 167). In Costa Rica, "an open economy became even more globalized with the development of tourism" (Lehoucq, 2010). And Panama increased its "relative prosperity ... as part of globalized financial, trade and commercial services and tourism" (Roniger, 2011, p.85).

\subsection{Hypothesis 7}

There is no relationship between the number of roads in the country and the nine measures of public wellbeing.

"World War II ... prompted an accelerated effort for land access to the Panama Canal ... and the US Army Corps of Engineers ... moved into each Central American republic with US cost-plus-fee contractors" ... then, after the war, the US Bureau of Public Roads "cooperative BPR-Republic program took over ... the project to open a 'Military Road' ... along the general route" of the IAH (Wood, 2013).

"Neo-liberal solutions to the economic and social underdevelopment of the region ... (included) completion of the Inter-American Highway ... (and) improvement in the condition and number of paved or all-weather roads throughout Central America ... Completion of the Inter-American Highway as far as Panama in $1964 \ldots$ facilitated ... interstate trade and industry as well as ... tourism" (Woodward, 1999, p. 293).

There was a "massive road reconstruction phase, funded with loans tied to neoliberal development projects" (Moodie, 2010, p. 10). But leftists typically resisted greater penetration by "foreign capital" (Torres-Rivas 1993, 104) and Indians generally resisted further assimilation with people of European descent. Older members of indigenous groups "recall their negative experiences when the first wave of non-indigenous settlers came during the construction of the Inter-American Highway" (Campregher, 2010, p. 792).

Roads "build by pioneer settlers in new areas encourage(d) further settlement" (Biesanz, Biesanz \& Biesanz, 1999, p. 135). And "physical integration ... through a network of roads ... advanced cultural integration" (Torres-Rivas, 1993, p. 120). Throughout Central America, planters encroached on "the communal land of the Indians" (Woodward, 2008, p. 112). Roads "would open to the outside world great tracks of good land ... (but) the losers were the campesinos, most of them Indians ... (who) turned more and more to cooperation with the left-wing guerrilla movements" (Anderson, 1988, p. 31).

There is also cooperation between proletarians and environmentalists as exemplified by the Environmental Project on Central America (Weinberg, 1991, p. 47). Red is usually green. But there is a "rift between leftists and ecologists in Central America" since "relocated peasants penetrate the rainforest along the logging roads and initiate the vicious cycle of jungle slash-and-burn agriculture" (ibid, p. 111, 24). And a rift emerged between leftists and Indians when the communist "Sandinistas looked to the large-scale development of the Miskito rainforest" (ibid, p. 91). The underlying unity of such protest movements is nevertheless assured since all rely on the same scapegoats, neoliberal policy and its embodiment in the US of A.

\subsection{Hypothesis 8}

There is no relationship between the number of whites in the country and the nine measures of public wellbeing.

In Central America, "anti-yanqui nationalist rhetoric" is practically synonymous with communist hatemongering (Harding, 2006, p. 63). Left-wing groups, so-called "Popular Forces" have long denounced "Yankee imperialism" claiming that the "duties and objectives of the revolution ... were to overthrow the reactionary military dictatorship and Yankee imperialism" (Anderson, 1988, p. 89, 93).

A leader of the FSLN was quite candid in saying: "We are anti-Yankee, we are opposed to the bourgeoisie, we are guided by scientific doctrine, by Marxism-Leninism" (Anderson, 1988, p. 221). And, the left branded any opposition to its party line, including an election they were likely to lose, as "yanqui imperialism" (Allison, 2010, p. 110).

In 1930, "Sandino attracted leftist sympathizers ... and his anti-Yankee movement made him a natural hero of Marxists everywhere" (Woodward, 1999, p. 200). In 1979, the jingoistic battle hymn of the Sandinistas called for "Nicaraguans to "fight against the Yankee, the enemy of humanity" (Walker \& Wade, 2011, p. 205).

The Sandinista "comandantes ... shared a ... deep antipathy toward capitalism and toward the United States, and a conviction that Marxism held the key to social progress" (Kinzer, 1991, p. 177). "Ortega was the exemplar of Latin American guerrilla leaders, proud of his anti-Americanism" (ibid, 223). 
The left was adept at "incorporating 'race' into its analysis and strategy ... adopting a model of 'internal colonialism' ... one that viewed ... society in specifically racial terms" (Grandin, 2011, p. 290). In the 1940s, labor organizers in Belize "called for the expulsion of whites" (Twigg, 2006, p. 133). But the situation there is much different today. A "Retired Persons Incentive Act was passed in ... 1999 ... to encourage qualified retirees ... to come to Belize - but only if they're from the US, Britain, Northern Ireland, or Canada" (ibid, p. 219).

Traditionally, there was resentment against whites because "foreign-owned plantations generally produced higher yields than did native-owned plantations" (Woodward, 2008, p. 116). But "the ever greater numbers of North American tourists, exchange students, and retirees" ... went hand in hand in developing "pro-Yankee attitudes" despite some lingering anti-Yankee resentment (Biesanz, Biesanz \& Biesanz, 1999, p. 120).

In Costa Rica, "foreigners integrated relatively easily into the society ... (and) in processing and manufacturing ... foreigners, who had both capital and technical experience ... came to play an important role" (Woodward, 1999, p. 183-4). And "Costa Rica promoted immigration of North American retirees as another source of income and land development" (ibid, p. 293-4). So, at least in some parts of Central America, the saying is "Yankee come here" not "Yankee go home."

\subsection{Hypothesis 9}

There is no relationship between fertility and the nine measures of public wellbeing.

The massive unemployment, the cheap labor, and the "widening gap in income distribution" that "hurled Central Americans toward social crisis and fratricidal war" were perhaps more a product of "the high rates of demographic expansion" than "the natural expropriating tendency of agrarian capitalism" (Torres-Rivas, 1993, p. 119, 95).

In 1966, the annual rate of demographic growth in Central America was "one of the world's greatest: 3.5 percent" (ibid, p. 112). "Poverty was growing ... as real wages declined behind inflation and population growth" (Woodward, 1999, p. 275).

But "much of the Latin American left ... (was) almost as puritanical about birth control as the Catholic Church. Leftists widely view(ed) family planning as a neo-colonial conspiracy, or even inherently genocidal" even though "fertility ... (was) consistently and inversely related to household income" (Weinberg, 1991, p. 148, 152).

In Nicaragua, "Sandinista policy toward birth control was not as revolutionary as ... expected ... Abortion was never legalized ... (and) the country's population continued to rise in the post-Sandinista period" (Walker \& Wade, 2011, p. 121). In this regard, Communist ideology was aligned not only with Liberation Theology but also with traditional Catholicism.

"At the urging of the Catholic Church, abortion ... (was) banned under all circumstances - including rape, and where the mother faces death - in ... Honduras, Nicaragua and ... El Salvador ... (and) in ... other countries it ... (was) highly restricted ... The strict laws ... (were) certainly not pro-choice - but their results ... (were) hardly ... pro-life either" since many women died "owing to complications resulting from backstreet abortions" ("Miscarriages of Justice," 2013).

Communists and Catholics remained united in their opposition to birth control. And over-population became a severe problem in Central America. "Rapid population growth put serious strains on Costa Rica's social security, medical care, and other progressive social programs by the 1990s" and these problems were exacerbated by "the migration of approximately 400,000 Nicaraguans into the country during the 1980s" (Woodward, 1999, p. 233).

Overpopulation continues to be a problem in the region contributing to both poverty and crime. And, not surprisingly, people continue to vote with their feet. "At least 15\% of Central Americans ... have (already) emigrated, most to the United States" ("Tormented Isthmus," 2011). And their remittances have now "become a vital part of the Central America economies" (Booth, Wade \& Walker, 2010, p. 235-6).

Neoliberalism has however contributed to some "remarkable improvements in family planning services in Central America ... (and) technical and financial support from development agencies (such as the United States Agency for International Development and the United Nations Population Fund) ... have helped these countries improve their family planning services" (Siow, 2009).

\section{Measures of the Explanatory Variable, Public Policy}

First, public policy with regard to business is operationalized using two measures: one for economic freedom and another for corporate taxation. Each operates along a continuum between a laissez-faire approach and an interventionist approach. 


\subsection{Economic Freedom}

Each country is scored on a scale from 100 to 0 , ranging from most to least economic freedom, according to the Index of Economic Freedom compiled by the Heritage Foundation (2012). A high score reflects a neo-liberal policy orientation.

\subsection{Corporate Taxation}

The corporate income tax rate in each country is reported by PricewaterhouseCoopers (2013). A high rate reflects a socialist policy orientation.

Second, public policy with regard to ethics is operationalized using two measures: one for gender equality and another for corruption. Each operates along a continuum between professionalism and cronyism.

\subsection{Gender Equality}

Each country is scored on a scale from 1 to 0 , ranging from equality to inequality, according to the Global Gender Gap Index featured on the World Economic Forum (2011). A high score reflects a neo-liberal policy orientation.

\subsection{Corruption}

The percentage of the population victimized by corruption in each country is reported by the Latin American Public Opinion Project in Political Culture of Democracy: Democratic Consolidation in the Americas in Hard Times (Seligson \& Smith, 2010c). A high percentage reflects a socialist policy orientation.

Third, public policy with regard to openness is operationalized using four measures: two external and two internal. The external measures of openness are trade and tourism. The internal measures of openness are the number of roads in a country and the number whites in a country. Each operates along a continuum between cosmopolitanism and isolationism.

\subsection{Trade}

Annual trade per capita in US dollars is reported for each country on the Global Platform on Business and Biodiversity by the Convention on Biological Diversity (2010). A high level of trade reflects a neo-liberal policy orientation.

\subsection{Tourism}

Annual receipts from tourism in millions of US dollars are reported for each country in Time Almanac 2013 published by Encyclopedia Britannica (King, 2012). A high level of tourism reflects a neo-liberal policy orientation.

\subsection{Number of Roads}

The ratio of roads in kilometers to area in square kilometers is calculated for each country using data reported in the World Factbook published by the Central Intelligence Agency (2012e). A large number of roads in a country reflects a neo-liberal policy orientation.

\subsection{Number of Whites}

The percentages of whites in the populations of El Salvador, Honduras, Nicaragua, and Panama are reported in a field listing of ethnic groups in the World Factbook published by the Central Intelligence Agency (2012a). The missing data for Costa Rica and Guatemala are calculated as averages of the percentages reported in Time Almanac 2013 published by Encyclopedia Britannica (King, 2012) and in the 2011 Latinobarometer published by the International Institute for Democracy and Electoral Assistance (2012, p. 59). The missing figure for Belize is calculated from the Belize Housing and Population Census (2010, p. 5) as the sum of the Caucasian/White and Mennonite groups divided by the total population. A large number of whites in a country reflects a neo-liberal policy orientation.

Fourth, public policy with regard to contraception is operationalized using a single measure: fertility. It operates along a continuum between prochoice and prolife. But fertility also serves as a partial substitute for longitudinal analysis. This study is contemporary or synchronic as opposed to chronological or diachronic. Temporal extrapolation is therefore impossible. But an increase or decrease with respect to each measure of the dependent variable can tentatively be projected through its correlation with fertility.

\subsection{Fertility}

The fertility rate expressed as the average number of births per woman is reported for each country under World Development Indicators by the World Bank (2010). A high rate reflects a socialist policy orientation. Fertility is also employed as a trend indicator with respect to the nine measures of public wellbeing. 


\section{Measures of the Dependent Variable, Public Wellbeing}

First, public wellbeing is operationalized using three economic measures: GDP per capita, lost income, and poverty rate.

\subsection{GDP per Capita}

Annual gross domestic product per capita expressed as current prices in US dollars is reported for each country in the World Economic Outlook Database of the International Monetary Fund (2011). A high level is indicative of a superior outcome.

\subsection{Lost Income}

The percentage of the population experiencing a decrease in household income is reported for each country by the Latin American Public Opinion Project in Political Culture of Democracy: Democratic Consolidation in the Americas in Hard Times (Seligson \& Smith, 2010b). A high percentage is indicative of an inferior outcome.

\subsection{Poverty Rate}

The percentage of the population below the poverty line is reported for each country in the World Factbook published by the Central Intelligence Agency (2012d). A high rate is indicative of an inferior outcome.

Second, public wellbeing is operationalized using four societal measures: literacy rate, homicide rate, life expectancy, and lost satisfaction.

\subsection{Literacy Rate}

The percentage of the population age 15 and over who can read and write is reported for each country in the World Factbook published by the Central Intelligence Agency (2012c). A high rate is indicative of a superior outcome.

\subsection{Homicide Rate}

The annual intentional homicide rate per 100,000 population in each country is reported by the United Nations Office on Drugs and Crime (2010). A high rate is indicative of an inferior outcome.

\subsection{Life Expectancy}

Average life expectancy at birth expressed in the number of years is reported for each country in the World Factbook published by the Central Intelligence Agency (2012b). A high number is indicative of a superior outcome.

\subsection{Lost Satisfaction}

The percentage of the population expressing a decline in life satisfaction is reported for each country by the Latin American Opinion Project in Political Culture of Democracy: Democratic Consolidation in the Americas in Hard Times (Seligson \& Smith, 2010a). A high percentage is indicative of an inferior outcome.

Third, public wellbeing is operationalized using two holistic measures: the Human Development Index and the Environmental Performance Index.

\subsection{HDI}

Each country is scored on a scale from 1 to 0 , ranging from most to least developed, according to the Human Development Index compiled by the United Nations Development Program (2012). A high score is indicative of a superior outcome.

\subsection{EPI}

Each country is scored on a scale from 100 to 0, ranging from best to worst, according to the Environmental Performance Index complied at Yale University (2012). In place of the missing figure for Belize, the average of the other six figures is used. A high score is indicative of a superior outcome. 
Table 1. Observed values for the nine measures of the explanatory variable, public policy

\begin{tabular}{llllllllll}
\hline & E-Free & C-Tax & G-Equ & Corru & Trade & Tour & Roads & Whites & Fert \\
\hline Belize & 61.9 & 24.7 & .649 & 17.2 & 04862 & 0291 & .132 & 04.3 & 2.8 \\
Costa Rica & 68.0 & 18.9 & .727 & 10.1 & 06033 & 2029 & .745 & 58.5 & 1.8 \\
El Salvador & 68.7 & 17.0 & .657 & 11.4 & 02370 & 0847 & .525 & 09.0 & 2.3 \\
Guatemala & 60.9 & 25.9 & .623 & 21.2 & 01729 & 1055 & .132 & 14.5 & 4.0 \\
Honduras & 58.8 & 26.6 & .695 & 16.2 & 02215 & 0557 & .127 & 01.0 & 3.1 \\
Nicaragua & 57.9 & 22.9 & .725 & 12.1 & 01447 & 0255 & .160 & 17.0 & 2.6 \\
Panama & 65.2 & 12.5 & .704 & 09.4 & 10124 & 1185 & .161 & 10.0 & 2.5 \\
Average & 63.1 & 21.2 & .683 & 13.9 & 04111 & 0888 & .283 & 16.3 & 2.7 \\
\hline
\end{tabular}

Table 2. Observed values for the nine measures of the dependent variable, public wellbeing

\begin{tabular}{llllllllll}
\hline & GDP/c & LostInc & Poverty & Literac & Homici & LifeExp & LostSat & HDI & EPI \\
\hline Belize & 4349 & 28.6 & 43.0 & 76.9 & 41.4 & 68.3 & 43.1 & .70 & 57.1 \\
Costa Rica & 8877 & 21.0 & 24.2 & 94.9 & 11.3 & 77.9 & 27.0 & .77 & 69.0 \\
El Salvador & 3855 & 40.6 & 36.5 & 81.1 & 64.7 & 73.7 & 40.8 & .68 & 52.1 \\
Guatemala & 3182 & 32.2 & 54.0 & 69.1 & 41.4 & 71.2 & 33.5 & .58 & 51.9 \\
Honduras & 2116 & 35.3 & 60.0 & 80.0 & 82.1 & 70.7 & 41.1 & .63 & 52.5 \\
Nicaragua & 1239 & 34.4 & 46.2 & 67.5 & 13.6 & 72.2 & 41.2 & .60 & 59.2 \\
Panama & 8514 & 16.1 & 29.0 & 91.9 & 21.6 & 78.0 & 23.0 & .78 & 57.9 \\
Average & 4590 & 29.7 & 41.8 & 80.2 & 39.4 & 73.1 & 35.7 & .68 & 57.1 \\
\hline
\end{tabular}

The observed values for the nine measures of the explanatory variable and the nine measures of the dependent variable are shown in Tables 1 and 2. Some of these measures can also be found in a global study entitled "The Blame Game in International Relations" (Craig, 2011).

\section{Methods and Findings}

Data are analyzed using IBM SPSS Statistics for Windows, Version 19.0 (2010). Univariate statistics for each of the 18 measures are computed. Tests for normality are conducted including tests for both skewness and kurtosis. But descriptives are not shown due to size constraints. Pearson correlation includes all 18 measures. Results are checked using SAS OnDemand for Academics, SAS Enterprise Guide 4.3 (2010).

Skewness describes a distribution that is lopsided as opposed to bell-shaped. A test result of zero indicates that the distribution of observed values is perfectly symmetric around the mean. A test result of plus or minus 1 is indicative of an approximately normal distribution but plus or minus 2 is acceptable for most purposes. And the test results for all 18 measures fall within that wider range.

Kurtosis describes a distribution that is pointed or flat as opposed to bell-shaped. A test result of zero indicates that the distribution of observed values is perfectly symmetric around the mean. A test result of plus or minus 1 is indicative of an approximately normal distribution but plus or minus 2 is acceptable for most purposes. And the test results for all 18 measures fall within that wider range except for whites at 5.3.

Although Quartile-Quartile Plots of each measure are examined and discussed, they are not included due to space limitations. For most measures, the data points resemble the line that represents a normal distribution on a Normal Q-Q Plot. Outliers are discussed in conjunction with the tests that follow.

The data for each measure are also subjected to the Shapiro-Wilk test for normality. If the p-value is more than the predetermined alpha level of .05, then the null hypothesis is not rejected. And it is concluded that the data are normally distributed. But if the p-value is .05 or less, then the null hypothesis is rejected. And it is concluded that the data are not normally distributed. 
Shapiro-Wilk tests are conducted for the nine measures of the explanatory variable, public policy. Two of the nine p-values are .05 or less. So in both instances the null hypothesis is rejected. It appears that the data for roads and whites are not normally distributed.

This is due in part to outliers that are recognizable on the Normal Q-Q Plots. With respect to roads the observed values for Costa Rica and El Salvador are .745 and .525 respectively compared to the mean of .283. With respect to whites, the observed value for Costa Rica is 58.5 compared to the mean of 16.3. These two less than bell-shaped distributions are especially problematic inasmuch as roads and whites are the only internal measures of openness.

A lesser complication exists with respect to trade. The p-value is above .05 but only slightly compared to the remaining six measures of the explanatory variable. An outlier is recognizable on the Normal Q-Q Plot. The observed value for Panama is 10,124 compared to the mean of 4,111. And, since trade is an external measure of openness, only one unblemished measure of openness remains: tourism.

Shapiro-Wilk tests are conducted for the nine measures of the dependent variable, public welbeing. All p-values are more than .05. So in every instance the null hypothesis is not rejected. It appears that the data for all nine measures are normally distributed.

Two of the nine are nonetheless somewhat questionable. The test results for lost satisfaction and EPI are above .05 but only slightly compared to the other seven measures of the dependent variable. And an outlier is recognizable on the Normal Q-Q Plot for EPI. The observed value for Costa Rica is 69.0 compared to the mean of 57.1. But the Kolmogorov-Smirnov test result for EPI indicates a normal distribution.

A minor concern exists with respect to GDP per capita. The Shapiro-Wilk test result is well above .05 but not as much as the remaining six measures of the dependent variable. And two outliers are recognizable on the Normal Q-Q Plot. The observed values for Costa Rica and Panama are 8,877 and 8,514 respectively compared to the mean of 4,590 .

16 of the 18 measures pass the Shapiro-Wilk test for normality indicating bell-shaped distributions of data. Only the measures for roads and whites are problematic. And the extreme outliers in both datasets represent only one country, Costa Rica. Rather than omit these two observed values, it is possible to interpret them as evidence of best practices from a neo-liberal point of view.

All 18 measures are continuous on either an interval or ratio scale. One of the nine explanatory measures, tourism, is on an interval scale. Likewise, one of the nine dependent measures, life expectancy, is on an interval scale. Two of the explanatory measures, economic freedom and gender equality, are also on an interval scale albeit as indicies. Likewise, two of the dependent measures, HDI and EPI, are also on an interval scale albeit as indicies. The remaining six measures of the explanatory variable are ratios. Likewise, the remaining six measures of the dependent variable are ratios.

Since all 18 of the measures are continuous and 16 of the 18 distributions are normal, Pearson product-moment correlation is used to calculate the linear association and statistical significance for each pair. In the 18 by 18 matrix, there are total of 324 pairs including 18 identities and 153 duplicates.

Within the 153 pairs of interest, 36 compare the nine measures of public policy with one another, 36 compare the nine measures of public wellbeing with one another, and 81 compare the nine measures of public policy with the nine measures of public wellbeing.

In each of the 153 tests, it is objectively hypothesized that zero correlation exists between the two measures of interest. But in most instances the results are considerably different from zero and in many cases significantly different despite the small sample size of seven. All numbers are conventionally rounded. A number is rounded up if the number to its right is five or more.

The magnitude of linear correlation ranges between +1 indicating a perfectly positive or direct relationship and -1 indicating a perfectly negative or inverse relationship. Zero is indicative of no linear association between the two measures of interest.

Using absolute numbers, results less than .3 are considered to be indicative of a small degree of association, results of .3 or more but less than .5 indicative of a medium degree of association, and results of .5 or more indicative of a large degree of association.

The .5 or more threshold is possibly too low for the natural sciences especially those relying on laboratory experiments with adequate controls and sophisticated instruments. But it is possibly too high for the social sciences especially those relying on field studies with complicating factors and random surveys. 
Table 3. Pearson correlation for measures of the explanatory variable, public policy

\begin{tabular}{llllllllll}
\hline & E-Free & C-Tax & G-Equ & Corru & Trade & Tour & Roads & Whites & Fert \\
\hline Econ Freedom & 1.00 & -.73 & 0.02 & -.56 & 0.47 & 0.69 & 0.81 & 0.47 & -.63 \\
Corp Taxation & -.73 & 1.00 & -.35 & 0.83 & -.73 & -.47 & -.42 & -.24 & 0.64 \\
Gend Equality & 0.02 & -.35 & 1.00 & -.76 & 0.32 & 0.25 & 0.31 & 0.49 & -.68 \\
Corruption & -.56 & 0.83 & -.76 & 1.00 & -.54 & -.37 & -.55 & -.40 & 0.90 \\
Trade & 0.47 & -.73 & 0.32 & -.54 & 1.00 & 0.47 & 0.13 & 0.21 & -.44 \\
Tourism & 0.69 & -.47 & 0.25 & -.37 & 0.47 & 1.00 & 0.73 & 0.81 & -.38 \\
Roads & 0.81 & -.42 & 0.31 & -.55 & 0.13 & 0.73 & 1.00 & 0.79 & -.73 \\
Whites & 0.47 & -.24 & 0.49 & -.40 & 0.21 & 0.81 & 0.79 & 1.00 & -.54 \\
Fertility & -.63 & 0.64 & -.68 & 0.90 & -.44 & -.38 & -.73 & -.54 & 1.00 \\
\hline
\end{tabular}

In the 36 tests involving just public policy, only five (14 percent) are less than absolute .3 whereas 13 (36 percent) are .3 or more but less than .5 and 18 (50 percent) result in an absolute correlation of 0.5 or above. Pearson correlations for measures of the explanatory variable are presented in Table 3.

Table 4. Pearson correlation for measures of the dependent variable, public wellbeing

\begin{tabular}{llllllllll}
\hline & GDP/c & LostInc & Poverty & Literac & Homici & LifeExp & LostSat & HDI & EPI \\
\hline GDP/capita & 1.00 & -.86 & -.86 & 0.90 & -.49 & 0.79 & -.85 & 0.92 & 0.64 \\
Lost Income & -.86 & 1.00 & 0.63 & -.68 & 0.65 & -.63 & 0.85 & -.76 & -.64 \\
Poverty Rate & -.86 & 0.63 & 1.00 & -.76 & 0.62 & -.80 & 0.64 & -.87 & -.71 \\
Literacy Rate & 0.90 & -.68 & -.76 & 1.00 & -.19 & 0.78 & -.69 & 0.93 & 0.56 \\
Homicide Rate & -.49 & 0.65 & .62 & -.19 & 1.00 & -.51 & 0.55 & -.36 & -.76 \\
Life Expectancy & 0.79 & -.63 & -.80 & 0.78 & -.51 & 1.00 & -.86 & 0.70 & 0.58 \\
Lost Satisfaction &.- .85 & 0.85 & 0.64 & -.69 & 0.55 & -.86 & 1.00 & -.63 & -.49 \\
HDI & 0.92 & -.76 & -.87 & 0.93 & -.36 & 0.70 & -.63 & 1.00 & 0.61 \\
EPI & 0.64 & -.64 & -.71 & 0.56 & -.76 & 0.58 & -.49 & 0.61 & 1.00 \\
\hline
\end{tabular}

In the 36 tests involving just public wellbeing, only one ( 3 percent) is less than absolute .3 whereas three ( 8 percent) are .3 or more but less than .5 and 32 ( 89 percent) result in an absolute correlation of .5 or above. Pearson correlations for measures of the dependent variable are presented in Table 4.

The strength of correlation between measures of the explanatory variable is high as is the strength of correlation between measures of the dependent variable. And the direction of correlation is consistent: neo-liberal orientations are negatively associated with socialist orientations; and, superior outcomes are negatively associated with inferior outcomes. So all measures appear to measure in fact what they purport to measure in theory.

In the 81 tests involving both public policy and public wellbeing, only five ( 6 percent) are less than absolute .3 whereas 22 (27 percent) are .3 or more but less than .5 and 54 ( 67 percent) result in an absolute correlation of .5 or above. Correlations between measures of the explanatory variable and measures of the dependent variable are presented in Table 5. The nine columns of explanatory measures correspond to the nine hypotheses listed in the literature review.

The magnitude of correlation is impressive between measures of the explanatory variable and measures of the dependent variable. And the direction of correlation is consistent in all 81 tests. The six neo-liberal orientations are positively associated with the five superior outcomes whereas the three socialist orientations including the trend indicator are positively associated with the four inferior outcomes. Likewise, the six neo-liberal orientations are negatively associated with the four inferior outcomes whereas the three socialist orientations including the trend indicator are negatively associated with the five superior outcomes. 
Table 5. Pearson correlation for measures of the explanatory variable, public policy, and measures of the dependent variable, public wellbeing

\begin{tabular}{llllllllll}
\hline & E-Free & C-Tax & G-Equ & Corru & Trade & Tour & Roads & Whites & Fert \\
\hline GDP/capita & $\mathbf{0 . 7 3}$ & $\mathbf{- . 7 2}$ & 0.30 & -.55 & $\mathbf{0 . 8 8}$ & $\mathbf{0 . 8 1}$ & 0.53 & 0.58 & -.55 \\
Lost Income & -.28 & 0.51 & -.39 & .39 & $\mathbf{- . 9 1}$ & -.57 & -.11 & -.44 & 0.31 \\
Poverty Rate & $\mathbf{- . 8 1}$ & $\mathbf{0 . 8 4}$ & -.41 & $\mathbf{0 . 7 8}$ & $\mathbf{- . 7 2}$ & $\mathbf{- . 6 5}$ & $\mathbf{- . 6 9}$ & $\mathbf{- . 6 2}$ & $\mathbf{0 . 8 1}$ \\
Literacy Rate & $\mathbf{0 . 7 3}$ & $\mathbf{- . 6 9}$ & 0.45 & $\mathbf{- . 6 6}$ & $\mathbf{0 . 7 9}$ & $\mathbf{0 . 7 4}$ & 0.60 & 0.49 & $\mathbf{- . 6 8}$ \\
Homicide Rate & -.13 & 0.38 & -.47 & 0.42 & -.44 & -.38 & -.22 & $\mathbf{- . 6 3}$ & 0.37 \\
Life Expectancy & $\mathbf{0 . 6 6}$ & $\mathbf{- . 8 4}$ & 0.58 & $\mathbf{- . 7 9}$ & $\mathbf{0 . 6 6}$ & $\mathbf{0 . 8 0}$ & 0.60 & $\mathbf{0 . 6 2}$ & $\mathbf{- . 6 2}$ \\
Lost Satisfaction &.- .47 & $\mathbf{0 . 6 5}$ & -.32 & 0.42 & $\mathbf{- . 7 7}$ & $\mathbf{- . 8 1}$ & -.30 & -.53 & 0.24 \\
HDI & $\mathbf{0 . 7 2}$ & $\mathbf{- . 7 6}$ & 0.39 & $\mathbf{- . 6 9}$ & $\mathbf{0 . 8 9}$ & 0.59 & 0.50 & 0.42 & $\mathbf{- . 7 3}$ \\
EPI & 0.33 &.- .31 & $\mathbf{0 . 7 0}$ & $\mathbf{- . 5 6}$ & 0.45 & 0.60 & 0.60 & $\mathbf{0 . 8 7}$ & $\mathbf{- . 7 0}$ \\
\hline
\end{tabular}

Bold type indicates "significant" probability.

The significance of correlation is also impressive given the small sample size of seven. The p-value for 16 (20 percent) of the 81 pairs is .05 or less; but, the p-value for 38 ( 47 percent) of the 81 pairs is .1 or less. Using the alpha level of .1 or less, it is possible to reject the null hypothesis for almost half the pairs and conclude that significant linear relationships exist.

A probability-value above .1 suggests that the correlation coefficient was the result of a mere chance or a small sample. Since a high p-value typically characterizes a low correlation and a low p-value a high correlation, the two test results are best interpreted jointly.

In this study, results are generalized with respect to each exploratory measure. The null hypothesis is rejected if the number of strong correlation coefficients plus the number of significant p-values is 10 or more out of a possible total of 18, i.e. more than half. And conclusions are then drawn with respect to the direction of association.

\subsection{Hypothesis 1}

There is no relationship between economic freedom and the nine measures of public wellbeing. This hypothesis is rejected since five of the nine correlations are strong with an absolute value of .5 or more and five of the nine are significant with a p-value of .1 or less.

The direction of correlation indicates that the neo-liberal orientation involving economic freedom is positively associated with the five superior outcomes and negatively associated with the four inferior outcomes.

\subsection{Hypothesis 2}

There is no relationship between corporate taxation and the nine measures of public wellbeing. This hypothesis is rejected since seven of the nine correlations are strong with an absolute value of .5 or more and six of the nine are significant with a p-value of .1 or less.

The direction of correlation indicates that the socialist orientation involving corporate taxation is negatively associated with the five superior outcomes and positively associated with the four inferior outcomes

\subsection{Hypothesis 3}

There is no relationship between gender equality and the nine measures of public wellbeing. This hypothesis is NOT rejected since only two of the nine correlations are strong with an absolute value of .5 or more and only one of the nine is significant with a p-value of .1 or less. It is therefore concluded that no relationship exists between gender equality and public wellbeing.

\subsection{Hypothesis 4}

There is no relationship between corruption and the nine measures of public wellbeing. This hypothesis is rejected since six of the nine correlations are strong with an absolute value of .5 or more and four of the nine are significant with a p-value of .1 or less.

The direction of correlation indicates that the socialist orientation involving corruption is negatively associated with the five superior outcomes and positively associated with the four inferior outcomes 


\subsection{Hypothesis 5}

There is no relationship between trade and the nine measures of public wellbeing. This hypothesis is rejected since seven of the nine correlations are strong with an absolute value of .5 or more and seven of the nine are significant with a p-value of .1 or less.

The direction of correlation indicates that the neo-liberal orientation involving trade is positively associated with the five superior outcomes and negatively associated with the four inferior outcomes.

\subsection{Hypothesis 6}

There is no relationship between tourism and the nine measures of public wellbeing. This hypothesis is rejected since eight of the nine correlations are strong with an absolute value of .5 or more and five of the nine are significant with a p-value of .1 or less.

The direction of correlation indicates that the neo-liberal orientation involving tourism is positively associated with the five superior outcomes and negatively associated with the four inferior outcomes.

\subsection{Hypothesis 7}

There is no relationship between the number of roads in a country and the nine measures of public wellbeing. This hypothesis is NOT rejected. Although six of the nine correlations are strong with a value of absolute .5 or more, only one of the nine is significant with a p-value of .1 or less. It is therefore concluded that no relationship exists between the number of roads in a country and public wellbeing.

\subsection{Hypothesis 8}

There is no relationship between the number of whites in a country and the nine measures of public wellbeing. This hypothesis is rejected since seven of the nine correlations are strong with an absolute value of .5 or more and four of the nine are significant with a p-value of .1 or less.

The direction of correlation indicates that the neo-liberal orientation involving the number of whites in a country is positively associated with the five superior outcomes and negatively associated with the four inferior outcomes.

\subsection{Hypothesis 9}

There is no relationship between fertility and the nine measures of public wellbeing. This hypothesis is rejected since six of the nine correlations are strong with an absolute value of .5 or more and five of the nine are significant with a p-value of .1 or less.

The direction of correlation indicates that the socialist orientation involving fertility (which doubles as a trend indicator) is negatively associated with the five superior outcomes and positively associated with the four inferior outcomes.

\section{Conclusion}

Only two of the nine hypotheses are not rejected. The results suggest that there is no relationship between public wellbeing and two measures of public policy: gender equality and the number of roads in a country. But there is evidently a relationship between public wellbeing and the remaining seven measures of public policy: economic freedom, corporate taxation, corruption, trade, tourism, the number of whites in a country, and fertility. Each of the seven relationships supports the claims of neo-liberals as opposed to the claims of socialists. And the seventh, fertility (doubling as a trend indicator), indicates that prospects for the region are not good.

Since this study is descriptive rather than inferential or predictive, except with regard to fertility, the issue of probability is left to the discretion of the reader. But the strength of association and the direction of association between measures of the explanatory variable and measures of the dependent variable are clear. And the practical significance of the findings is abundantly clear even if the statistical significance is not.

A one-tailed test would result in a smaller p-value. But testing the possibility of a relationship in only one direction ignores the possibility of a relationship in the opposite direction. A larger sample size with the same mean would also result in a smaller p-value. But the seven countries are a select and unique subset, a purposive sample as opposed to a random sample. This is an area study as opposed to a global study. Indeed it is somewhat unique "since most scholarly writing on Central America continues to focus on the individual states rather than on the entire region" (Roniger, 2011, p. xii).

The temporal focus of this research is as narrow as the geographic focus. Only recent data are employed. This study is contemporary rather than longitudinal. The direction of cause and effect is therefore assumed rather than tested. "The question of whether good political systems precede or follow the development of vibrant economies 
has generated much controversy" (Lehoucq, 2010). In $19^{\text {th }}$ century Central America, "positivists believed that economic growth and prosperity were necessary before true political democracy could be established" (Leonard, $2011,76)$. And, in the $20^{\text {th }}$ century, dependentistas believed that "development without parallel democratization" was the problem (Torres Rivas, 1993, 115).

In either case, the question is like asking which came first, the chicken or the egg? It is difficult to have one without the other. Political and economic matters are inseparable, hence the study of political-economy. But, government is supposed to govern and to govern well. So, in this study, it is assumed that public policy is the "cause" or explanatory variable whereas public wellbeing is the "effect" or dependent variable.

A cross-sectional design is employed to examine a particular region at a particular time. So any inference to another place or another period risks the propagation of a universal fallacy. The results presented here are nonetheless extremely persuasive with regard to a single domain: the subcontinent of North America after the first decade of the $21^{\text {st }}$ century.

There are however other issues that require attention. Because this study is exploratory, many indicators of public policy and public wellbeing are not included. And some extraneous measures could produce different results. So additional research along these lines is required.

This study is also observational as opposed to experimental and the analysis is bivariate as opposed to multivariate. No attempt is made to control or manipulate explanatory measures and only a rudimentary attempt is made to ascertain the relative importance of explanatory measures. More sophisticated statistical techniques therefore need to be employed.

An additional complication arises because the dichotomous nature of politics is extremely complex. Sometimes it is difficult to classify a public policy as capitalist or socialist. And sometimes it is difficult to classify a socialist policy as neo-fascist or neo-communist (Kinzer, 1991, p. 166, 179, 230) (Arevalo, 2011, p. 210). To further complicate matters, there are various neo-Nazi and neo-Marxist factions.

On the right, "traditional parties ... Liberals and Conservatives ... simply ... represent rival factions within the landed oligarchy" (Anderson, 1998, p. 175). "A new landed aristocracy composed of Liberals ... became as inbred and aristocratic as their Conservative predecessors" (Woodward, 1999, p. 168). There was not only a "façade 'competition' between the traditional Liberals and Conservatives" (Walker \& Wade, 2011, p. 181) there was also "a series of 'Liberal' dictators" (Grandin, Levenson \& Oglesby, 2011, p. 110). "Because both doctrines shared the same methods, it became impossible to distinguish conservatives from liberals" (Arevalo, 2011, p. 207). Examples of more radical right-wing groups in Central America include Somocistas and counter-revolutionaries or "contras" in Nicaragua (Anderson, 1998, p. 209-10) as well as the White Hand (Mano Blanco) in Guatemala (Woodward, 1999, 246-7). They more closely resemble the National Socialist German Workers' Party or Nazis.

On the left, "labor organization in Central America became identified with Marxism early" (Woodward, 1999, p. 208). Parties within the party included Leninists, Trotskyites, Stalinists, and Maoists (Anderson, 1988, p. 122). Left-wing factions ranged from less radical groups such as dependentistas to more radical groups such as Sandinistas. Even groups such as the Sandinista National Liberation Front were "riddled with factionalism" and "tendencies" (ibid, p. 181, 189). "Sindicatos (labour movements) and ligas campesinas (peasant movements) ... (were) part of the vanguard of the guerrilla movement ... (along with) student unions and ... Catholic" universities inspired by "liberation theology" (Leeuwen, 2010, p. 98, 104) and Jesuit faculty (Didion, 1982, p. 82).

But a "free-market democracy ... structured around individual responsibility" stands out among more extreme forms of government (Moodie, 2010, p. 41, 3). And specific propositions drawn from the literature of the region not only make it possible to hypothesize with respect to measures of interest, they also make it possible to categorize measures of the explanatory variable, public policy, as either capitalist or socialist.

This research is deliberately secondary rather than primary. Both variables, public policy and public wellbeing, are operationalized using measures and data taken from reliable secondary sources. Although this approach is indicative of less effort, it is also indicative of less subjectivity and more credibility.

In the words of Manuel Montufar y Coronado (1791-1844), "People can eat neither theories nor beautiful principles" (Roniger, 2011, p. 28). But this study is more practical than conceptual. The logic of capitalist policy, its internal validity, is not the focus but the result of capitalist policy, its external validity, is. And the findings presented here lend considerable support to neoliberal claims. Likewise, the logic of socialist policy, its internal validity, is not the focus but the result of socialist policy, its external validity, is. And the findings presented here lend no support to neo-fascist or neo-communist claims. 
Right wingers and left wingers can eat their words. But will they? According to the trend indicator, fertility, the outlook for the region is not bright. And the implications for the United States are similarly ominous especially with respect to the smuggling of illicit drugs and illegal aliens and with regard to the security of "American" tourists and the "Panamanian" canal. So the practical significance of this research is not confined to Central America.

Despite the dismal forecast and the turbulent history of the region, it is still possible to hope for the best as did Simon Bolivar in his Jamaica Letter of 1815:

The States of the Isthmus from Panama to Guatemala will perhaps form a confederation. This magnificent location between the two great oceans could in time become the emporium of the world. Its canals will shorten the distances throughout the world, strengthen commercial ties with Europe, America, and Asia, and bring that happy region tribute from the four quarters of the globe. Perhaps someday the capital of the world may be located there, just as Constantine claimed Byzantium was the capital of the ancient world (Woodward, 1999, 94) (Roniger, 2011, p. 27).

But confederation may or may not lead to integration beyond the region. "During the heyday of import substitution industrialization, between 1965 and $1982 \ldots$ the Central American Common Market ... erected trade barriers with the rest of the world" (Lehoucq, 2010). Conversely, the recent Central America Free Trade Agreement "immediately eliminates all tariffs on 80 percent of US manufactured goods, with the remainder phased out over a few years" (Florida Enterprise, 2013). The matter of integration is further complicated by the findings of a recent study. "Regionalism pursued by countries via their respective regional organizations was found to have no significant independent effects on economic development" (Kim, 2012, p. 255).

In any case, confederation does not require centralization. It only requires cooperation. Indeed, "the catastrophic economic declines ... and the hemispheric transitions away from authoritarian rule combined to create a widespread decentralizing impulse throughout the region" since the turn of the millennium (Ryan, 2004, p. 81). "Decentralization tends to be incorporated into a broad framework of state reform that is informed by the market-oriented critique of traditional statist development models" (ibid).

"The only enemy is totalitarianism in any guise" (Didion, 1982, p. 99), whether fascist or communist. In the words of Lord Acton, "Power tends to corrupt, and absolute power corrupts absolutely." Any government that robs Peter to pay Paul is inherently unjust whether it is a police state that exploits the labor of the poor or a welfare state that expropriates the property of the rich. And, since organized violence and war are more dangerous than disorganized violence and crime, it more important for people to regulate government than for government to regulate people. It is not oxymoronic to point out that anarchy is associated with tyranny since the results of "illegal looting" are similar to the results of "legal looting." Neither should be confused with capitalism and producing.

Although a "post-ideological world" is unimaginable (Moodie, 2010, p. 83), the new world order may involve not only "a deconstruction of the nation-state ... bisected as power shifts to higher "macro-regional" levels on the one hand and lower "micro-regional" levels on the other ... (but also) a disaggregation of the mixed political economy ... bifurcated as socialism (control) is used at upper levels of human aggregation to alleviate pollution and as capitalism (freedom) is used at lower levels to alleviate poverty" (Craig, 2010, p. 414). The new world order may also involve a "new separation of powers" (Ackerman, 2000, p. 634) "that assigns the more political and the more technical functions to different parts of government ... (including) non-partisan institutions ... (such as) an autonomous central bank" (Lehoucq, 2010). But neither the new world order nor Central America's part is yet apparent.

\section{References}

Ackerman, B. (2000). The new separation of powers. Harvard Law Review, 113(3), 634-725.

Allison, M. E. (2010). The legacy of violence on post-civil war elections: The case of El Salvador. Studies in Comparative International Development, 45, 104-124. http://dx.doi.org/10.2307/1342286

Anderson, T. P. (1988). Politics in Central America (2nd ed.). New York, NY: Praeger.

Arevalo, J. J. (2011). A New Guatemala. In G. Grandin, \& E. Oglesby (Eds.), The Guatemala reader: History, culture, politics (pp. 206-210). Durham, NC: Duke University Press.

Belize Population and Housing Census. (2010). Population by ethnicity. Retrieved November 15, 2012, from http://www.statisticsbelize.org.bz/dms20uc/dynamicdata/docs/20110505004542_2.pdf

Biesanz, M., Biesanz, R., \& Biesanz, K. (1999). The Ticos: Culture and social change in Costa Rica. Boulder, CO: Lynne Rienner Publishers. 
Booth, J. A., Wade, C. J., \& Walker, T. W. (2010). Understanding Central America (5th ed.). Boulder, CO: Westview Press.

Campregher, C. (2010). Shifting perspectives on development: An actor-network study of a dam in Costa Rica. Anthropological Quarterly, 83(4), 783-804. http://dx.doi.org/10.1353/anq.2010.0019

Central Intelligence Agency (CIA). (2012a). Field Listing: Ethnic groups. In World Factbook. Retrieved November 11 , 2012 , from https://www.cia.gov/library/publications/the-world-factbook/fields/print_2075.html

Central Intelligence Agency (CIA). (2012b). Life expectancy at birth. In World Factbook. Retrieved November 13, 2012, from https://www.cia.gov/library/publications/the-world-factbook/wfbExt/region_cam.html

Central Intelligence Agency (CIA). (2012c). Literacy age 15 and over. In World Factbook. Retrieved November 13, 2012, from https://www.cia.gov/library/publications/the-world-factbook/wfbExt/region_cam.html

Central Intelligence Agency (CIA). (2012d). Poverty rate by country. In World Factbook. Retrieved November 13, 2012, from https:/www.cia.gov/library/publications/the-world-factbook/wfbExt/region_cam.html

Central Intelligence Agency (CIA). (2012e). Roads by country. In World Factbook. Retrieved November 13, 2012, from https://www.cia.gov/library/publications/the-world-factbook/wfbExt/region_cam.html

Convention on Biological Diversity (CBD). (2010). Trade per capita. In Global Platform on Business and Biodiversity. Retrieved May 3, 2013, from http://www.cbd.int/en/business/home

Craig, K. (2010). The new world order: A deconstruction of the nation-state and a disaggregation of the mixed political economy. International Journal of Public Administration, 33, 414-420. http://dx.doi.org/10.1080/01900691003750739

Craig, K. (2011). The blame game in international relations. National Social Science Journal, 35(2), 43-55.

Didion, J. (1982). Salvador. New York, NY: Simon and Schuster.

Drug War Hits Central America. (2011, April 14). Economist. Retrieved November 15, 2012, from http://www.economist.com

Florida Enterprise. (2013). What is CAFTA? In the CAFTA Intelligence Center. Retrieved June 22, 2013, from http://www.caftaintelligencecenter.com/subpages/What_is_CAFTA.asp

Grandin, G. (2011). A Clandestine Life. In G. Grandin, D. Levenson, \& E. Oglesby (Eds.), The Guatemala reader: History, culture, politics (pp. 287-294). Durham, NC: Duke University Press.

Grandin, G., Levenson, D., \& Oglesby, E. (Eds.). (2011). The Guatemala reader: History, culture, politics. Durham, NC: Duke University Press.

Hale, C. R. (2011). The Authorized Indian. In G. Grandin, D. Levenson, \& E. Oglesby (Eds.), The Guatemala reader: History, culture, politics (pp. 517-522). Durham, NC: Duke University Press.

Harding, R. C. (2006). The History of Panama. Westport, CT: Greenwood Press.

Heritage Foundation. (2012). Index of Economic Freedom. Retrieved November 11, 2012, from http://www.heritage.org/index/ranking

Horton, L. (2006). Contesting state multiculturalisms: Indigenous land struggles in Eastern Panama. Journal of Latin American Studies, 38, 829-858. http://dx.doi.org/10.1017/S0022216X06001623

IBM SPSS Statistics for Windows, Version 19.0. (2010). Armonk, NY: IBM Corp.

International Institute for Democracy and Electoral Assistance (IDEA). (2012). White ethnic group. In 2011 Latinobarometer. $\quad$ Retrieved November $15, \quad 2012, \quad$ from $\mathrm{http} / / / \mathrm{www}$. idea.int/americas/2011-latinobarometer-pessimism-increases.cfm

International Monetary Fund. (2011). Gross domestic product per capita. In World Economic Outlook Database. Retrieved November 16, 2012, from http://www.imf.org/external/pubs/ft/weo/2012/01/weodata/weorept.aspx?sy=2011\&ey=2011\&scsm=1\&ssd $=1 \&$ sort $=$ country $\& \mathrm{ds}=. \& \mathrm{br}=1 \& \mathrm{c}=268 \% 2 \mathrm{C} 339 \% 2 \mathrm{C} 278 \% 2 \mathrm{C} 283 \% 2 \mathrm{C} 238 \% 2 \mathrm{C} 253 \% 2 \mathrm{C} 258 \& \mathrm{~s}=\mathrm{NGDP} \mathrm{R} \%$ 2CNGDP_RPCH $\% 2$ CNGDP\%2CNGDPD $\% 2 C N G D P \_D \% 2 C N G D P R P C \% 2 C N G D P P C \% 2 C N G D P D P C \%$ 2CPPPGDP\%2CPPPPC $\% 2$ CPPPSH $\% 2$ CPPPEX\%2CNID_NGDP\%2CNGSD_NGDP\%2CPCPI\%2CPCPI PCH\%2CPCPIE\%2CPCPIEPCH\%2CTM_RPCH\%2CTMG_RPCH\%2CTX_RPCH\%2CTXG_RPCH\%2C TXGO $\% 2$ CTMGO $\% 2$ CLUR $\% 2$ CLP\%2CGGR\%2CGGR_NGDP\%2CGGX\%2CGGX_NGDP\%2CGGXC 
NL\%2CGGXCNL_NGDP\%2CGGSB\%2CGGXONLB\%2CGGXONLB_NGDP\%2CGGXWDN\%2CGGX WDN_NGDP\%2CGGXWDG\%2CGGXWDG_NGDP\%2CNGDP_FY\%2C-

BCA $\% 2 C B C A \_N G D P D \& g r p=0 \& a=\& p r . x=37 \&$ pr.y $=23 \#$ download

Kim, H. (2012). Regionalism, globalization and economic development in the world. In S. Bojnec, J. Brada, \& M. Kuboniwa (Eds.), Overcoming the crisis: Economic and financial developments in Asia and Europe (pp. 255-265). Koper, Slovenia: University of Primorska Press.

King, T. (Ed.). (2012). Tourism by country. In Time Almanac 2013. Chicago, IL: Encyclopedia Britannica.

Kinzer, S. (1991). Blood of brothers: Life and war in Nicaragua. Cambridge, MA: Harvard University Press.

Leeuwen, M., van. (2010). To conform or to confront? CSOs and agrarian conflict in post-conflict Guatemala. Journal of Latin American Studies, 42, 91-119. http://dx.doi.org/10.1017/S0022216X10000064

Lehoucq, F. (2010). Political competition, constitutional arrangements, and the quality of public policies in Costa

Leonard, T. M. (2011). The History of Honduras. Santa Barbara, CA: Greenwood.

Levenson, D. T. (2011). Life on the edge. In G. Grandin, D. Levenson, \& E. Oglesby (Eds.), The Guatemala reader: History, culture, politics (pp. 302-308). Durham, NC: Duke University Press.

Marti i Puig, S. (2010). The adaptation of the FSLN: Daniel Ortega's leadership and democracy in Nicaragua (C.

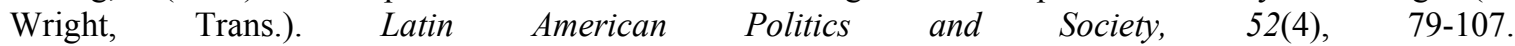
http://dx.doi.org/10.1111/j.1548-2456.2010.00099.x

Medina, L. K. (2010). When government target "the state": Transnational NGO government and the state in Belize. Political and Legal Anthropology Review, 33(2), 245-263.

Miscarriages of Justice. (2013, June 8). Economist, p. 40.

Molina, I., \& Palmer, S. (1998). The History of Costa Rica. San Jose, Costa Rica: Editorial de la Universidad de Costa Rica.

Moodie, E. (2010). El Salvador in the aftermath of peace: Crime, uncertainty and the transition to democracy. Philadelphia, PA: University of Pennsylvania Press.

Out of Control. (2013, March 9). Economist, p. 37.

Perez-Brignoli, H. (1989). A brief history of Central America (R. B. Sawrey et al., Trans.). Berkeley, CA: University of California Press.

PricewaterhouseCoopers (PwC). (2013). Total tax rate. In Paying taxes: The global picture. Retrieved May 2, 2013, from http://www.pwc.com/gx/en/paying-taxes/download-order.jhtml

Rica. Latin American Politics and Society, 52(4), 53-111. http://dx.doi.org/10.1111/j.1548-2456.2010.00098.x

Rogers, D. (2012). Nicaragua's gangs: Historical legacy or contemporary symptom? NACLA Report on the Americas, 45(1), 66-69.

Roniger, L. (2011). Transnational Politics in Central America. Gainesville, FL: University of Florida Press.

Ryan, J. J. (2004). Decentralization and democratic instability: The case of Costa Rica. Public Administration Review, 64(1), 81-91. http://dx.doi.org/10.1111/j.1540-6210.2004.00348.x

SAS Enterprise Guide 4.3. 2010. Cary, NC: SAS OnDemand for Academics. Retrieved June 3, 1013, from $\mathrm{http}: / /$ www.sas.com/govedu/edu/programs/od_academics.html

Seligson, M. \& Smith, A. E. (Eds.). (2010a). Decline in life satisfaction. In Political culture of democracy: Democratic consolidation in the Americas in hard times. Retrieved November 11, 2012, from http://www.vanderbilt.edu/lapop/ab2010/2010-comparative-en-revised.pdf

Seligson, M. \& Smith, A. E. (Eds.). (2010b). Household income decreased. In Political culture of democracy: Democratic consolidation in the Americas in hard times. Retrieved November 11, 2012, from http://www.vanderbilt.edu/lapop/ab2010/2010-comparative-en-revised.pdf

Seligson, M. \& Smith, A. E. (Eds.). (2010c). Victimized by corruption. In Political culture of democracy: Democratic consolidation in the Americas in hard times. Retrieved November 11, 2012, from http://www.vanderbilt.edu/lapop/ab2010/2010-comparative-en-revised.pdf 
Siow, C. (2009). Family planning use in Central America: Closing the equity gap. Washington, DC: Population $\begin{array}{lllll}\text { Reference } \quad \text { Bureau. } & \text { Retrieved } & \text { 2012, } & \text { from }\end{array}$ http://www.prb.org/Articles/2009/centralamericafamilyplanning.aspx

Surprising Safe Haven (2012, January 28). Economist. Retrieved November 15, 2012, from http://www.economist.com/

Thomson, P. A. B. (2004). Belize: A concise history. Oxford, UK: Macmillan Education.

Tormented Isthmus. (2011, April 14). Economist. Retrieved November 15, 2012, from http://www.economist.com

Torres-Rivas, E. (1993). History and society in Central America (Sullivan-Gonzales, D., Trans.). Austin, TX: University of Texas Press.

Twigg, A. (2006). Understanding Belize. Madeira Park, BC: Harbour Publishing.

United Nations Development Program (UNDP). (2012). International Human Development Indicators (HDI). Retrieved May 30, 2013, from http://hdr.undp.org/en/countries

United Nations Office on Drugs and Crime (UNODC). (2010). Intentional homicide by country. Retrieved November 18, 2012, from http://data.un.org/Data.aspx?d=UNODC\&f=tableCode\%3A1

Velasquez-Nimatuj, I. A. (2011). Transnationalism and Maya dress. In G. Grandin, D. Levenson, \& E. Oglesby (Eds.), The Guatemala reader: History, culture, politics (pp. 302-308). Durham, NC: Duke University Press.

Walker, T. W. \& Wade, C. J. (2011). Nicaragua: Living in the shadow of the Eagle (5th ed.). Boulder, CO: Westview Press.

Weinberg, B. (1991). War on the land: Ecology and politics in Central America. London, UK: Zed Books.

Wolf, S. (2012). Policing crime in El Salvador. NACLA Report on the Americas, 45(1), 43-54.

Wood, N. (2013). Inter-American Highway 1940-1957. In Highway history: The trailblazers. Federal Highway Administration. Retrieved July 7, 2013, from http://www.fhwa.dot.gov/infrastructure/blazer009a.cfm

Woodward, R. L., Jr. (1999). Central America: A nation divided (3 ${ }^{\text {rd }}$ ed.). Oxford, UK: Oxford University Press.

Woodward, R. L., Jr. (2008). A short history of Guatemala. La Antigua, Guatemala: Editorial Laura Lee.

World Bank. (2010). Fertility rate by country. Retrieved November 11, 2012, from http://data.worldbank.org/indicator/SP.DYN.TFRT.IN

World Economic Forum. (2011). Global Gender Gap Report. Retrieved November 11, 2012, from http://www.weforum.org/reports/global-gender-gap-report-2011

Yale University. (2012). Environmental Performance Index (EPI). Retrieved May 9, 2013, from http://epi.yale.edu/epi2012/countryprofiles

Year of Living Less Dangerously. (2013, March 9). Economist, p. 38.

\section{Copyrights}

Copyright for this article is retained by the author(s), with first publication rights granted to the journal.

This is an open-access article distributed under the terms and conditions of the Creative Commons Attribution license (http://creativecommons.org/licenses/by/3.0/). 